\title{
Learning from history or the rationale for considering surgical correction of vesicoureteral reflux
}

\author{
Jonathan Riddell, MD, FRCSC; Julie Franc-Guimond, MD, FRCSC
}

Can Urol Assoc J 2010;4(4):280-3

$\mathrm{H}$ istory reminds us of valuable lessons learned in the treatment of vesicoureteral reflux (VUR). Rates of reflux nephropathy (RN) have decreased remarkably over the past 50 years, owing in various degrees to more rapid detection of urinary tract infection (UTI) in infants and children, improved medical therapy and timely surgical intervention. Reflux nephropathy once accounted for $22 \%$ of all pediatric renal transplantations, and now accounts for less than $6 \% .^{1}$ Despite this improvement, $8.5 \%$ of chronic renal disease in North American children is still due to RN. ${ }^{2}$ In some series, there is a history of childhood pyelonephritis with subsequent renal scarring in up to $15 \%$ of adult renal transplantation. ${ }^{3}$ Therefore, the modern day debate on the optimal management of VUR has significant merit in terms of preventing RN, and its impact on pediatric and adult populations.

During the 1950s, Hutch was the first to suggest a link between VUR, pyelonephritis and renal scars based on his work on adult paraplegics, and the benefits of ureteral reimplantation. ${ }^{4}$ Politano, Leadbetter, Paquin and others improved upon the concept of an adequate length, detrusor-backed submucosal tunnel, cementing ureteral reimplant as a timetested cornerstone in the management of VUR. 5,6 Reported contemporary success rates of antireflux surgery range from $96 \%$ to $98 \%$.

The VUR treatment paradigm shifted from surgery towards medical management during the late 1970s. Lenaghan and colleagues showed a natural tendency for most VUR to resolve spontaneously. ${ }^{8}$ This work, coupled with the work of Smellie and colleagues, ${ }^{9,10}$ which showed a low rate of new scar formation on daily low dose antimicrobial prophylaxis, provided the rationale for the expectant VUR treatment we have seen for the past 3 decades. The rationale of preventing UTIs and pyelonephritis, while the refluxing kidney is at risk, formed the basis of the 1997 American Urological Association expert panel on VUR, ${ }^{11}$ where surgery is reserved for patients who failed on antibiotic prophylaxis and with high-grade reflux.

\section{Issues with medical management}

Several recent publications have questioned the efficacy of daily antimicrobial prophylaxis in terms of preventing UTI and new renal scarring (Table 1). ${ }^{12-15}$ Breakthrough UTIs of up to $25 \%$ have been reported. This challenges the current assumption that daily antibiotic prophylaxis "prevents" UTIs, pyelonephritis and subsequent scar formation in affected renal units. Criticisms over the methodology of the aforementioned studies have led to great anticipation for the results of the Randomized Intervention for children with VesicoUreteral Reflux (RIVUR) study (Fig. 1). ${ }^{16}$

Adequately designed and powered, this study will hopefully answer the question of whether prophylaxis prevents UTI and scarring in VUR patients (and thus potentially validate VUR management for the past 3 decades). Post-RIVUR, lingering concerns will still remain about antimicrobial prophylaxis. These include (1) increased bacterial resistance; ${ }^{17}(2)$ the inconvenience and risk associated with serial radiologic investigations; (3) decreased cost-effectiveness ${ }^{18}$ (4) the clinical versus statistical significance of any result; ${ }^{19}$ and (5) the fate of those refluxers who do not resolve over time, in that we are shifting the progression of chronic renal disease into adulthood given the known, slow progression of reflux nephropathy.

Some proponents of medical therapy have proposed that early treatment of early pyelonephritis can decrease the risk or lessen scar formation. ${ }^{20}$ Two recent studies refute this idea. ${ }^{21,22}$ Hoberman and colleagues, in a large prospective trial of oral versus intravenous therapy for UTIs in young children, found no significant difference in scarring among children who presented after 24 hours of fever compared with those who presented sooner. ${ }^{21}$ Hewitt and colleagues used data from 2 multicentre, prospective, randomized controlled trials to demonstrate a $30.7 \%$ scar rate on dimercaptosuccinic acid (DMSA) 12 months after an acute pyelonephritis. ${ }^{22}$ Progressive delay in antibiotic treatment from $<1$ day to $>5$ days after onset of fever was not associated with increased scarring. In other words, prompt treatment of febrile UTI does not prevent associated scarring and/or the potential for RN.

\section{Advances in surgical technique}

While the debate over the efficacy of medical management continues, there must be an overt acknowledgement in any VUR debate that ureteral reimplantation cures reflux. With published minimal acceptable success rates of $95 \%$ 


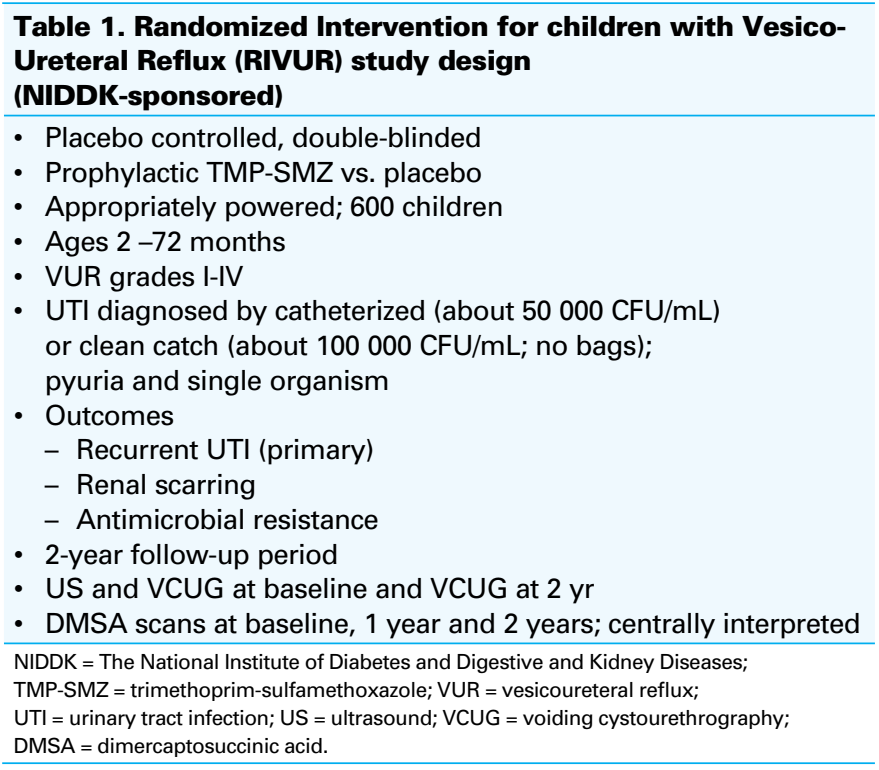

and reproducible results reported as high as $99 \%$, pediatric urologists have essentially perfected the art of the ureteral reimplant. At our institution, unilateral reimplantation is generally performed extravesically. Bilateral reimplantation is performed by an intravesical, cross-trigonal fashion to avoid the risk of transient postoperatively urinary retention observed with bilateral extravesical reimplantation ( $4 \%$ to $15 \%)$. Other reported complications of ureteral reimplantation include mild transient hydronephrosis in $6 \%$ to $7 \%$, and an overall rate of ureteral obstruction requiring revision in $<1 \%$.

The perioperative management of the child undergoing ureteral reimplantation has changed dramatically. Two-week hospital stays in the early series have evolved into outpatient or overnight stays. Routine placement of suprapubic catheters, ureteral stents and surgical drains have been abandoned, and most patients with uncomplicated ureteral reimplants are discharged on postoperative day 1 with no tubes in place.

Pediatric anesthesia has also improved greatly. Judicious use of anti-inflammatories and anticholinergics decrease narcotic requirements and relieve bladder spasms. Regional blocks and/or continuous epidural infusions help children recover quickly by providing pre-emptive and better pain control; these are the standard at our centre.

Finally, as laparoscopic, vesicoscopic and robotic approaches gain acceptance as equivalent or superior in terms of success, morbidity from ureteral reimplantation will be further reduced.

\section{Role of endoscopic bulking agents}

Endoscopic bulking agents represent an extension of the surgical armamentarium. Originally pioneered over 30 years ago as an alternative to ureteral reimplantation, ${ }^{23}$ endoscopic
Table 2. Vesicoureteral risk assessment

- Age of child at time of infection

- Gender

- Character of infection (pyelonephritis vs. cystitis)

- Status of renal parenchyma (scarring or dysplasia)

- Single vs. duplex renal system

- Functional status of the bladder

- Voiding pattern of the child

- Grade of reflux at presentation

- Family reliability/compliance

injection for VUR has undergone several modifications of technique, and injection material (polytetrafluoroethylene, silicone paste, collagen, dextranomer/hyaluronic acid copolymer). Currently, dextranomer/hyaluronic acid copolymer is the dominant injectable in part due to its biocompatibility (both contents are biodegradeable polysaccharides) and lack of migration (due to infiltration with endogenous connective tissue). Controversy exists as to the exact mechanism by which reflux is prevented, and success rates are highly variable $(60 \%$ to $90 \%$ ). At our institution, endoscopic injection has evolved into a common surgical intervention performed for VUR, especially for lower grade reflux. As with any emerging technology, long-term, prospective studies are needed to better define short- and long-term success and complications and to further clarify the role of endoscopic injection in treating VUR.

\section{Discussion}

From the original animal work of Ransley and Risdon, ${ }^{24}$ we know that reflux in and of itself is not a disease. Add, however, UTI to VUR, with the appropriate confluence of bacterial virulence and host factors, and renal scarring can ensue. Although the exact pathogenesis of renal scarring is not well-understood, the end result, reflux nephropathy, is understood, and could be entirely preventable.

Given that most reflux is self-limited, the key to any management strategy is selecting out the small minority of patients who are at risk for future deterioration. To avoid overtreatment, some authors are advocating a "top-down" approach to investigation of first febrile UTI. ${ }^{25}$ Rather than starting with voiding cystourethrography and identifying mainly "benign VUR," ultrasound and DMSA has become the first-line investigation. Recurrent UTI, and/or renal scars motivate cystography, which then contributes to stratification into low- and high-risk groups in terms of the potential for progressive renal damage. The presence of renal scars and reflux at initial presentation is associated with a 17-fold risk of progressive renal damage over the presence of reflux alone. Though we applaud the efforts to characterize at-risk populations, we do not condone an algorithm that waits for the disease process to become macroscopic before initiating therapy. Further prospective studies are necessary to better identify and characterize high-risk populations with VUR, as well as to validate surgical efficacy and other 
Table 3. Recent publications addressing antimicrobial prophylaxis

\begin{tabular}{|c|c|c|c|c|}
\hline Publication & Subjects & Age; reflux status & Study design & Findings \\
\hline $\begin{array}{l}\text { Garin et al. } \\
\text { (Pediatrics 2006) }\end{array}$ & $\begin{array}{l}236 \text { children with acute } \\
\text { pyelonephritis }\end{array}$ & $\begin{array}{l}3 \text { months to } 18 \text { years; } \\
\text { grades I-III reflux }\end{array}$ & $\begin{array}{l}12 \text { month prospective, } \\
\text { open label, randomized trial } \\
\text { comparing prophylaxis with } \\
\text { no prophylaxis }\end{array}$ & $\begin{array}{l}\text { Role for prophylaxis in } \\
\text { preventing recurrent UTI } \\
\text { and new renal scars is not } \\
\text { supported }\end{array}$ \\
\hline $\begin{array}{l}\text { Conway et al. } \\
\text { (JAMA 2007) }\end{array}$ & $\begin{array}{l}\text { Network of } 74974 \text { children; } \\
611 \text { first UTI; } 83 \text { recurrent } \\
\text { UTI }\end{array}$ & $\begin{array}{l}<7 \text { years; with or without } \\
\text { any grade of reflux }\end{array}$ & $\begin{array}{l}\text { Case-control trial to } \\
\text { determine risk factors } \\
\text { for recurrent UTI and } \\
\text { the association between } \\
\text { antimicrobial prophylaxis } \\
\text { and recurrent UTI }\end{array}$ & $\begin{array}{l}\text { Prophylaxis was not } \\
\text { associated with decreased } \\
\text { risk of recurrent UTI, } \\
\text { but was associated with } \\
\text { increased risk of resistant } \\
\text { infections }\end{array}$ \\
\hline $\begin{array}{l}\text { Roussey-Kessler et al. } \\
\text { (J Urol 2008) }\end{array}$ & $\begin{array}{l}225 \text { children with low grade } \\
\text { reflux }\end{array}$ & $\begin{array}{l}1 \text { month to } 3 \text { years; grades } \\
\text { I-III reflux }\end{array}$ & $\begin{array}{l}18 \text { month prospective, } \\
\text { randomized open label trial } \\
\text { comparing cotrimoxazole } \\
\text { or no treatment }\end{array}$ & $\begin{array}{l}\text { Prophylaxis does not } \\
\text { reduce the overall incidence } \\
\text { of urinary tract infection } \\
\text { in children with low grade } \\
\text { VUR }\end{array}$ \\
\hline $\begin{array}{l}\text { Montini et al. } \\
\text { (Pediatrics 2008) }\end{array}$ & $\begin{array}{l}338 \text { children after first } \\
\text { febrile UTI }\end{array}$ & $\begin{array}{l}2 \text { months to } 7 \text { years; with or } \\
\text { without non severe reflux }\end{array}$ & $\begin{array}{l}\text { Prospective, randomized, } \\
\text { open-label, 2-armed, non- } \\
\text { inferiority trial comparing } \\
\text { no prophylaxis with } \\
\text { prophylaxis }\end{array}$ & $\begin{array}{l}\text { Prophylaxis does not } \\
\text { reduce the rate of UTI for } 12 \\
\text { months after first UTI with } \\
\text { or without VUR }\end{array}$ \\
\hline
\end{tabular}

de novo strategies at preventing renal deterioration in these groups. A search at the molecular level for either a genetic or protein marker of susceptibility could be the eventual Rosetta stone for VUR management.

Until then, we believe every patient must be managed on a case-by-case basis. Multiple variables must be taken into account (Fig. 2). ${ }^{26}$ These variables can then be incorporated into evidence-based constructs, such as recently published nomograms ${ }^{27}$ quantifying the likelihood of reflux resolution. A move from experience-based to evidenced-based medicine is essential in moving forward.

\section{Conclusion}

Until the role of antimicrobial prophylaxis is clarified, surgical intervention in the form of ureteral reimplantation remains the gold standard for the prevention of reflux nephropathy in susceptible renal units.

Université de Montréal, CHU Sainte-Justine, Department of Surgery, Division of Pediatric Urology, Montréal, QC

Competing Interests: None declared.

This paper has been peer-reviewed.

\section{References}

1. Cendron M. Reflux nephropathy. J Pediatr Urol 2008;4:414-21.

2. Novak TE, Mathews R, Martz K, et al. Progression of chronic kidney disease in children with vesicoureteral reflux: the North American Pediatric Renal Trials Collaborative Studies Database. J Urol 2009;182(4Suppl):1678-81.
3. Coulthard MG. Vesicoureteric reflux is not a benign condition. Pediatr Nephrol 2009;24:227-32.

4. Hutch JA. Vesico-ureteral reflux in the paraplegic: cause and correction. J Urol 1952;68:457-69.

5. Politano VA, Leadbetter WF. An operative technique for the correction of vesicoureteral reflux. J Urol 1958;79:932-41.

6. Paquin AJ. Ureterovesical anastomosis: The description and evaluation of a technique. J Urol 1959;82:573.

7. Austin JC, CS Cooper. Vesicoureteral reflux: surgical approaches. Urol Clin N Am 2004;31:543-57.

8. Lenaghan $D$, Whitaker JG, Jensen $F$, et al. The natural history of reflux and long-term effects of reflux on the kidney. J Urol 1976;115:728-30.

9. Smellie JM, Normand IC. Bacteriuria, reflux, and renal scarring. Arch Dis Child 1975;50:581-5.

10. Smellie JM, Katz G, Gruneberg RN. Controlled trial of prophylactic treatment in childhood urinary tract infection. Lancet 1978;2:175-8.

11. Elder JS, Peters CA, Arant BS Jr, et al. Pediatric Vesicoureteral Reflux Guidelines Panel summary report on the management of primary vesicoureteral reflux in children. J Urol 1991;157:1846-51.

12. Conway PH, Cnaan A, Zaoutis T, et al. Recurrent urinary tract infections in children: risk factors and association with prophylactic antimicrobials. JAMA 2007;298:179-86.

13. Roussey-Kesler $\mathrm{G}$, Gadjos $\mathrm{V}$, Idres $\mathrm{N}$, et al. Antibiotic prophylaxis for the prevention of recurrent urinary tract infection in children with low grade vesicoureteral reflux: results from a prospective randomized study. J Urol 2008; 179:674-9.

14. Montini $G$, Rigon L, Zucchetta $P$, et al. Prophylaxis after first febrile urinary tract infection in children? A multicenter, randomized, controlled, noninferiority trial. Pediatrics 2008;122:1064-71.

15. Garin EH, Olavarria F, Garcia Nieto V, et al. Clinical significance of primary vesicoureteral reflux and urinary antibiotic prophylaxis after acute pyelonephritis: a multicenter, randomized, controlled study. Pediatrics 2006; 117:626-32

16. Mathews $R$, Carpenter $M$, Chesney $R$, et al. Controversies in the management of vesicoureteral reflux: the rationale for the RIVUR study. J Pediatr Urol 2009;5:336-41.

17. Chung A, Perera R, Brueggemann AB, et al. Effect of antibiotic prescribing on antibiotic resistance in individual children in primary care: prospective cohort study. BMJ 2007;335:429.

18. Hsieh MH, Swana HS, Baskin $L$, et al. Cost-utility analysis of treatment algorithms for moderate grade vesicoureteral reflux using Markov models. J Urol 2007;177:703-9; discussion 709.

19. Diaz M. Editorial comment. J Urol 2009;182:2445.

20. Coulthard MG, Verber I, Jani JC, et al. Can prompt treatment of childhood UTI prevent kidney scarring? Pediatr Nephrol 2009;24:2059-63.

21. Hoberman A, Wald ER, Hickey RW, et al. Oral versus initial intravenous therapy for urinary tract infections in young febrile children. Pediatrics 1999;104:79-86.

22. Hewitt IK, Zucchetta P, Rigon L, et al. Early treatment of acute pyelonephritis in children fails to reduce renal scarring: data from the Italian renal infection study trials. Pediatrics 2008;122:486-90.

23. Läckgren G, Kirsch AJ. Surgery Illustrated - Surgical Atlas Endoscopic treatment of vesicoureteral reflux. BJU Int 2010;105:1332-47.

24. Ransley PG, Risdon RA. Reflux and renal scarring. Br J Radiol 1978; 14(Suppl):1-35. 
25. Merrick MV, Notghi A, Chalmers N, et al. Long term follow up to determine the prognostic value of imaging after urinary tract infection. Part 1: reflux. Arch Dis Child 1995;72:388-92.

26. Caldamone AA. Commentary to "Controversies in the management of vesicoureteral reflux - the rationale for the RIVUR study": Urinary tract infections and vesicoureteral reflux in childen: What have we learned? J Pediatr Urol 2009:5:342-3.

27. Estrada CR Jr, Passerotti CC, Graham DA, et al. Nomograms for predicting annual resolution rate of primary vesicoureteral reflux: results from 2,462 children. J Urol 2009;182:1535-41.

\section{Rebuttal}

\section{Armando J. Lorenzo, MD, MSc, FRCSC, FAAP}

$\mathrm{D}$ r. Riddell and Dr. Franc-Guimond present a strong, thorough and thoughtful argument in favour of surgical intervention for the management of vesicoureteral reflux. ${ }^{1}$ It is particularly reassuring that we see eyeto-eye on important points, most notably the role of patient selection. Nevertheless, the main question that remains to be answered is not so much if we can surgically correct vesicoureteral reflux, but in whom should it be corrected. After all, let us consider that the elegantly portrayed historical evidence reflects overall improvements in medical care, with increased awareness, better diagnostic tools and advances in medical therapy, along with the surgical innovations described. Moreover, the idea that surgical intervention has played a major role in decreasing the incidence of end-stage renal disease secondary to reflux is debatable; published data (adjusting for changes in diagnostic practices) refute the contention that our treatment efforts have had a strong impact on this outcome. ${ }^{2}$

Adding to the debate is the somewhat heterogeneous group of interventions that "anti-reflux surgery" includes. This has to be well-defined, considering that the popular dextranomer/hyaluronic acid endoscopic injection has been reported to have unexpectedly high recurrence rates on longer-term follow-up..$^{3-6}$ Recently published data from the Swedish Reflux Trial in Children have not shown a difference in infection rates comparing antibiotic prophylaxis and endoscopic treatment groups; ${ }^{7}$ there was no evidence of new renal damage reported in the medical therapy group. ${ }^{8}$ Thus, confirmation that surgery is significantly better is hard to find; this unfortunately weakens our colleagues' stand and ultimate conclusion that surgery is the "gold standard" (particularly in terms of preventing long-term problems such as reflux nephropathy). Furthermore, statements challenging the potential benefits of medical therapy can also be called into question. For example, consider the studies listed in the provided table. ${ }^{1}$ Missing from this list of seminal publications is perhaps one of the best trials recently conducted on the topic, ${ }^{9}$ a randomized-controlled trial that showed benefit for those patients who received prophylaxis over placebo. Indeed, important criticisms of many of the studies that have shown lack of benefit from medical therapy include the problem with inadequate power of the trials. ${ }^{10}$ In addition, some
Correspondence: Dr. Julie Franc-Guimond, Associate Professor, Université de Montréal, CHU SainteJustine, Department of Surgery, Division of Pediatric Urology, A-4, 3175 Côte Sainte-Catherine, Montréal, QC H3T 1C5; julie.franc-guimond.hsj@ssss.gouv.qc.ca of the arguments about the lack of benefit in early treatment of pyelonephritis are based on data that may have significant shortcomings (such as the reliance on sub-group analyses ${ }^{11}$ ).

What can we make out of this debate? As indicated in the point/counterpoint article, my personal impression is that the controversy is sometimes erroneously approached. ${ }^{12}$ I firmly believe that one of the main problems with our management originates in the idea that there is an overall "superior approach," disregarding the principles of individualization. Patients are different in many underlying factors, some of which may be far more important than the mere presence of reflux or time-honoured descriptive characteristics (such as grade). At the end of the day, we should at least agree that better data are needed, that individualized patient care will play an increasingly important role in management and that long-term endpoints will trump the potentially meaningless early outcomes that we have often focused on until now.

\section{References}

1. Riddell J, Franc-Guimond J. Learning from history or the rationale for considering surgical correction of vesicoureteral reflux. Can Urol Assoc J 2010;4:280-3.

2. Craig JC, Irwig $L M$, Knight JF, et al. Does treatment of vesicoureteric reflux in childhood prevent end-stage renal disease attributable to reflux nephropathy? Pediatrics 2000;105:1236-41.

3. Chertin B, Kocherov $S$. Long-term results of endoscopic treatment of vesicoureteric reflux with different tissue-augmenting substances. J Pediatr Urol Epub 2009 Nov 5.

4. Holmdahl G, Brandstrom P, Lackgren G, et al. The Swedish reflux trial in children: II. Vesicoureteral reflux outcome. J Urol 2010;184:280-5.

5. Sedberry-Ross S, Rice DC, Pohl HG, et al. Febrile urinary tract infections in children with an early negative voiding cystourethrogram after treatment of vesicoureteral reflux with dextranomer/hyaluronic acid. I Urol 2008;180:1605-9; discussion 1610.

6. Lee EK, Gatti JM, Demarco RT, et al. Long-term followup of dextranomer/hyaluronic acid injection for vesicoureteral reflux: Iate failure warrants continued followup. J Urol 2009;181:1869-74; discussion 1874-5.

7. Brandstrom $P$, Esbjorner $E$, Herthelius $M$, et al. The Swedish reflux trial in children: III. Urinary tract infection pattern. J Urol 2010;184:286-91.

8. Brandstrom P, Neveus T, Sixt $R$, et al. The Swedish reflux trial in children: IV. Renal damage. J Urol 2010;184:292-7.

9. Craig JC, Simpson $J M$, Williams $G J$, et al. Antibiotic prophylaxis and recurrent urinary tract infection in children. N Engl J Med 2009;361:1748-59.

10. Hoberman A, Keren R. Antimicrobial prophylaxis for urinary tract infection in children. N Engl J Med 2009;361:1804-6.

11. Edmonson MB, Wald ER. Treatment of pyelonephritis and risk of renal scarring. Pediatrics 2009;123:e544545; author reply 545.

12. Lorenzo AJ. Medical versus surgical management for vesicoureteral reflux: the case for medical management. Can Urol Assoc J 2010;4:276-8. 